\section{Michigan Technological

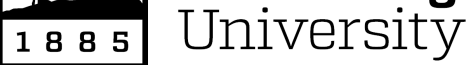

Michigan Technological University Digital Commons @ Michigan Tech

\title{
Effects on Amorphous Silicon Photovoltaic Performance from High-Temperature Annealing Pulses in Photovoltaic Thermal Hybrid Devices
}

\author{
M. Pathak \\ Queen's University - Kingston, Ontario \\ Joshua M. Pearce \\ Michigan Technological University \\ S. J. Harrison \\ Queen's University - Kingston, Ontario
}

Follow this and additional works at: https://digitalcommons.mtu.edu/materials_fp

\section{Recommended Citation}

M.J.M. Pathak, J.M. Pearce and, S.J. Harrison, "Effects on Amorphous Silicon Photovoltaic Performance from High-temperature Annealing Pulses in Photovoltaic Thermal Hybrid Devices" Solar Energy Materials and Solar Cells, 100, 199-203 (2012). http://digitalcommons.mtu.edu/materials_fp/42 
Published as: M.J.M. Pathak, J.M. Pearce and, S.J. Harrison, "Effects on Amorphous Silicon Photovoltaic Performance from High-temperature Annealing Pulses in Photovoltaic Thermal Hybrid Devices" Solar Energy Materials and Solar Cells, 100, 199-203 (2012).

http://dx.doi.org/10.1016/j.solmat.2012.01.015

\title{
Effects on Amorphous Silicon Photovoltaic Performance from High-temperature Annealing Pulses in Photovoltaic Thermal Hybrid Devices
}

\author{
M.J.M. Pathak ${ }^{\mathrm{a}}$, J.M. Pearce ${ }^{\mathrm{a}, \mathrm{b}^{*}}$ and, S.J. Harrison ${ }^{\mathrm{a}}$
}

${ }^{a}$ Department of Mechanical and Materials Engineering, Queen's University, Kingston, ON, Canada

b Department of Materials Science \& Engineering and Department of Electrical \& Computer Engineering, Michigan Technological University, Houghton, MI, USA

* Contact author: 601 M\&M Building, 1400 Townsend Drive, Houghton, MI 49931-1295 ph: 906-487-1466 fax: 906-487-2630 email: pearce@ mtu.edu

\begin{abstract}
There is a renewed interest in photovoltaic solar thermal (PVT) hybrid systems, which harvest solar energy for heat and electricity. Typically, a main focus of a PVT system is to cool the photovoltaic (PV) cells to improve the electrical performance, however, this causes the thermal component to under-perform compared to a solar thermal collector. The low temperature coefficients of amorphous silicon (a-Si:H) allow for the PV cells to be operated at higher temperatures and are a potential candidate for a more symbiotic PVT system. The fundamental challenge of a-Si:H PV is light-induced degradation known as the Staebler-Wronski effect (SWE). Fortunately, SWE is reversible and the a-Si:H PV efficiency can be returned to its initial state if the cell is annealed. Thus an opportunity exists to deposit a-Si:H directly on the solar thermal absorber plate where the cells could reach the high temperatures required for annealing.

In this study, this opportunity is explored experimentally. First a-Si:H PV cells were annealed for 1 hour at $100^{\circ} \mathrm{C}$ on a 12 hour cycle and for the remaining time the cells were degraded at $50^{\circ} \mathrm{C}$ in order to simulate stagnation of a PVT system for 1 hour once a day. It was found that, when comparing the cells after stabilization at normal $50^{\circ} \mathrm{C}$ degradation, this annealing sequence resulted in a $10.6 \%$ energy gain when compared to a cell that was only degraded at $50^{\circ} \mathrm{C}$.
\end{abstract}

Keywords: hydrogenated amorphous silicon; a-Si; annealing; Photovoltaic Thermal Hybrid; PVT; PV/T

\section{Introduction}

Photovoltaic solar thermal (PVT) hybrid systems have been shown to be more efficient at solar energy collection on the basis of exergy, energy and cost [1-7]. Most current PVT systems are based on crystalline silicon (c-Si) photovoltaic (PV) materials, whose performance declines with increasing temperature by $0.04 \% /{ }^{\circ} \mathrm{C}$ [8]. Thus, these PVT system designs are primarily focused on cooling the c-Si PV cells to maximize the electrical gain, while the extracted thermal energy is viewed as a secondary benefit [7]. The result of this design focus is that the thermal component of the PVT system significantly under-performs when compared to standard solar 
Published as: M.J.M. Pathak, J.M. Pearce and, S.J. Harrison, "Effects on Amorphous Silicon Photovoltaic Performance from High-temperature Annealing Pulses in Photovoltaic Thermal Hybrid Devices" Solar Energy Materials and Solar Cells, 100, 199-203 (2012).

http://dx.doi.org/10.1016/j.solmat.2012.01.015

thermal collectors [9-12]. Focusing the design on only maximizing solar electrical output thus prevents the PVT system from being optimized.

A potential solution to this challenge is to use a PV material that can operate at higher temperatures without substantial performance losses. One such promising material is hydrogenated amorphous silicon (a-Si:H), which has a temperature coefficient of only $-0.01 \%$ / ${ }^{\circ} \mathrm{C}$ [8], a quarter that of c-Si. A fundamental challenge recognized shortly after the discovery of the a-Si:H PV cell, was light-induced degradation of the a-Si:H PV performance known as the Staebler-Wronski effect (SWE) [13-17]. SWE causes defect states to form in the a-Si:H material when exposed to sunlight, which lower the efficiency of the PV cell. For commercial highquality a-Si:H materials, these defects saturate after a long ( 100 hours of continuous 1 sun) illumination and the efficiency of the cell is considered stabilized at this point [18-20]. This is stabilized state is known as the degraded steady-state (DSS). Fortunately, SWE is reversible and the a-Si:H PV cell efficiency can be returned to its initial state if the cell is heated to $150^{\circ} \mathrm{C}$ for four hours as the defect states are annealed [13, 21-23]. Various schemes have been devised to take advantage of thermal annealing in a-Si:H, such as removing the entire PV array and annealing them in an air oven at lower temperatures (e.g. at $80^{\circ} \mathrm{C}$ ) over extended times [24]. In addition, it has been found that a-Si:H PV performs better at higher temperatures since the optoelectronic properties of a-Si:H materials [25-27] stabilize at a higher efficiency [18,28]. In a solar thermal flat plate collector the temperature can easily reach over $100^{\circ} \mathrm{C}$ and even climb higher than $200^{\circ} \mathrm{C}$ if the system is stagnated [29]. Thus an opportunity exists to deposit a-Si:H directly on the solar thermal absorber plate [30,31] where the cells could reach the high temperatures required for annealing. This suggests that a-Si:H would be an excellent choice of PV material for a PVT system and that careful control of the temperature of the thermal side of the PVT could be used to introduce thermal annealing pulse cycles to raise the overall PV electrical conversion performance.

This paper explores this potential and reports on a series of experiments in which a-Si:H based PV cells were exposed to high temperature pulse annealing cycles for which the temperature and duration were determined by the potential stagnation conditions in a PVT system. The results are discussed to determine the value of utilizing a scheme of thermal cycling in PVT systems to maximize the overall solar energy harvested.

\section{Materials and Methods}

The a-Si:H PV cells used in this study were fabricated by an AKT plasma enhanced chemical vapour deposition (PECVD) chamber. The i-layer thicknesses of 210, 420, 630 and 840 $\mathrm{nm}$ were deposited by ThinSilicon in the following bottom up structure as can be seen in Figure 1: AGC float glass $(3 \mathrm{~mm}) / \mathrm{SnO}_{2}: \mathrm{F}(700 \mathrm{~nm})$ - textured fluorinated tin oxide/ Ag $(200 \mathrm{~nm}) / \mathrm{AZO}$ (100nm)/ n-a-Si:H (25nm)/ i-a:Si:H (210nm to 840 nm)/ p-a-Si:H (15nm)/ ITO (70nm).

\section{\{Insert Figure 1 Here\}}

The following sections describe the various methodologies required to complete and acquire the data for this study. 
Published as: M.J.M. Pathak, J.M. Pearce and, S.J. Harrison, "Effects on Amorphous Silicon Photovoltaic Performance from High-temperature Annealing Pulses in Photovoltaic Thermal Hybrid Devices" Solar Energy Materials and Solar Cells, 100, 199-203 (2012).

http://dx.doi.org/10.1016/j.solmat.2012.01.015

\subsection{Light-Induced Degradation}

A Newport class AAA solar simulator was used to apply AM1.5 1 sun illumination to the PV cells until a DSS was reached. Degradation temperatures were maintained with a Chemat Technology Inc. hot plate attached to a Cole Parmer Digi-Sense k-Type temperature controller. A k-type thermocouple was placed beside the cell to monitor and maintain surface temperature at the desired temperatures of $25^{\circ} \mathrm{C}$ (standard testing conditions for $\mathrm{PV}$ ), $50^{\circ} \mathrm{C}$ (representative operating temperature for PV) or $90^{\circ} \mathrm{C}$ (representative of operating temperatures for solar thermal systems) during the degradation. PV Measurements I-V Curve software K2400 I-V was used with a Keithley 2000 multimeter and a Keithley 2400 source meter to measure the currentvoltage output of the cells. An AutoIt macro was implemented to run the program to take the measurements at desired intervals.

\subsection{Spike Annealing at the DSS}

After reaching the DSS, the cells were exposed to a thermal annealing cycle (spike annealing) with a set point of $100^{\circ} \mathrm{C}$ for one hour. This test was to simulate stagnation of the thermal component of the PVT system. The $100{ }^{\circ} \mathrm{C}$ was determined as feasible by experimentally simulating stagnation using a test rig containing the PV cell array used in this study. It should be noted that this value is conservative due to the nature of the areas around the test cells, which were highly reflective. The 1 hour annealing time was considered a short enough period of time to not greatly affect the thermal system performance, but long enough to ensure a substantial annealing of the SWE defect states in the PV cell. The PV cell was then allowed to cool to its degraded temperatures of 90,50 and $25^{\circ} \mathrm{C}$, respectively and remained at these temperatures for at least 10 minutes to obtain an accurate temperature correlation.

\subsection{Spike Annealing Cycle}

Following the methods outlined in Section 2.1 and 2.2, a spike annealing cycle test was completed on a 12 hour cycle. The cell was degraded at $50^{\circ} \mathrm{C}$ for 10 hours and 45 minutes, at which time the surface temperature of the cell was raised to $100^{\circ} \mathrm{C}$ over approximately 15 minutes and was maintained at that temperature for 1 hour and then allowed to cool naturally to $50^{\circ} \mathrm{C}$. It should be noted that the typical operating temperature for a PV module is $50^{\circ} \mathrm{C}$ [32].

\section{Results and Discussion}

It is known that a-Si:H PV when degraded at higher temperatures will stabilize at higher efficiencies, as can be seen in Figure 2 showing the normalized maximum power $\left(\mathrm{P}_{\max }\right)$ with a $630 \mathrm{~nm}$ i-layer thick a-Si:H cell degraded at 25, 50 and $90^{\circ} \mathrm{C}$ [19].

\section{\{Insert Figure 2 Here\}}

From Figure 2, it can be easily determined that running an a-Si:H cell at higher temperatures will increase the energy output of the cell due to the earlier occurrence of the DSS. This supports the concept of using a-Si:H in PVT systems as a-Si:H cells stabilize at higher efficiencies at higher operating temperatures. However, it would be more beneficial to the 
Published as: M.J.M. Pathak, J.M. Pearce and, S.J. Harrison, "Effects on Amorphous Silicon Photovoltaic Performance from High-temperature Annealing Pulses in Photovoltaic Thermal Hybrid Devices" Solar Energy Materials and Solar Cells, 100, 199-203 (2012).

http://dx.doi.org/10.1016/j.solmat.2012.01.015

overall energy conversion if the cell could retain its initial efficiency rather than operate at the DSS lower efficiency. In order to test if this was possible, high-temperature annealing pulses (or spike annealing) were investigated. The spike annealing process was applied to the stabilized cells of the temperature series found in Figure 2 and the results are shown for degradation temperatures of 25, 50 and $90^{\circ} \mathrm{C}$, respectively, in Figures 3-5. In each graph, the fill factor (FF), maximum power and annealing temperature profile are plotted as a function of time. The FF indicates the quality of the cell performance as the ratio of actual power output to theoretical power output.The annealing temperature profile displays the change in temperature over time applied to the cell. It should be noted that the end points of each line segment are known, but changes between them are not displayed for clarity.

\section{\{Insert Figure 3 Here\} \\ \{Insert Figure 4 Here\} \\ \{Insert Figure 5 Here\}}

As can be seen in Figures 3-5, there are some interesting patterns that arise at all degradation temperatures investigated. During the ramp up in temperature, the power drops initially, but then slowly increases thereafter. This may be because the cell initially suffers from the rapid increase in the temperature during the ramp until it is closer to achieving surface cell temperatures of 100 ${ }^{\circ} \mathrm{C}$ required for the annealing process to take a significant effect [24]. Although a-Si:H PV do perform better at higher temperatures to a point, cells are also very sensitive to fluctuations in temperature. This can clearly be seen in Figures $4-5$ at the $100{ }^{\circ} \mathrm{C}$ plateau, where the temperature fluctuated by a couple degrees resulting in a wavelike scattered pattern during this period. In all three annealing tests, the FF spiked at around $80{ }^{\circ} \mathrm{C}$ whereas the power reaches its maximum at temperatures lower than $50{ }^{\circ} \mathrm{C}$. These findings can be explained by understanding the temperature relationships between the short circuit current $\left(I_{s c}\right)$ and open circuit voltage $\left(V_{o c}\right)$. $I_{s c}$ increases with temperature slightly, whereas the $\mathrm{V}_{\text {ос }}$ decreases significantly with temperature, typically 3-4 times as fast. Therefore, at $80{ }^{\circ} \mathrm{C}$ the conditions are set such that the $\mathrm{I}_{\mathrm{sc}}$ has only dropped a little while the $\mathrm{V}_{\text {ос }}$ has increased significantly with the result being a greatly increased FF. At $50{ }^{\circ} \mathrm{C}$, the $\mathrm{V}_{\text {oc }}$ has increased dramatically allowing for a larger maximum voltage and therefore greatly increasing the $\mathrm{P}_{\max }$ output.

Reconsidering Figure 2, it is clear that the starting points for cycles shown in Figures 3-5 are dependent on what temperature the cells are degraded. As mentioned before, the higher the temperature, the faster the DSS and higher the corresponding $\mathrm{P}_{\max }$. At the lower degraded temperatures in Figures 3-4, the annealing has a larger effect on the power increase compared to the higher temperature in Figure 5. This is expected given that the DSS $\mathrm{P}_{\max }$ is highest at $90{ }^{\circ} \mathrm{C}$, such that the power gain is smaller when being annealed at increase in temperature of only 10 degrees. To compare the relative regeneration of the cells, the final $\mathrm{P}_{\max }$ in Figures 3-5 were divided by the initial $\mathrm{P}_{\max }$ in Figure 2, which resulted in percentage regenerations of $84.1 \%$, $86.2 \%$ and $96.8 \%$ for the $25^{\circ} \mathrm{C}, 50^{\circ} \mathrm{C}$ and $90{ }^{\circ} \mathrm{C}$ degradations respectively. Thus, at the highest degradation temperature, the cell is almost fully regenerated in the spike annealing, even though the gain is the smallest. This can be understood again by noting that the cell stabilizes at a higher $\mathrm{P}_{\max }$ at higher temperature. 
Published as: M.J.M. Pathak, J.M. Pearce and, S.J. Harrison, "Effects on Amorphous Silicon Photovoltaic Performance from High-temperature Annealing Pulses in Photovoltaic Thermal Hybrid Devices" Solar Energy Materials and Solar Cells, 100, 199-203 (2012).

http://dx.doi.org/10.1016/j.solmat.2012.01.015

The degradation at $50{ }^{\circ} \mathrm{C}$ and relevant spike annealing cycles were completed for different i-layer thicknesses (i.e., 210, 420, 630 and $840 \mathrm{~nm}$ ) to determine if there was a potential to use spike annealing to enable thicker cells (with higher efficiencies) than those currently used in industry. It was found that the patterns of response were consistent for all PV cells with different i-layer thicknesses as seen in Figure 6. Figure 6 shows the maximum power of 4 cell thickness PV devices as a function of time. The different shades of the symbols indicate the different temperature stages of the pulse annealing test: i) ramp up, ii) $100{ }^{\circ} \mathrm{C}$ plateau, iii) cooling down, iv) $50{ }^{\circ} \mathrm{C}$ plateau and v) cooling down again. The darker regions indicate the temperature plateaus of the spike annealing.

\section{\{Insert Figure 6 Here\}}

For the thinner the cell, the effect of a one hour spike anneal on the power of the cell is greatest. This is by virtue of the thicker cells having more material, which means they have more defect states that require a greater annealing time [33, 34]. Therefore, after the 1 hour of annealing, the thicker cells will have more defects remaining, which negatively impact their relative performance. It is clear that all a-Si:H PV devices, regardless of thickness between 200nm and 800nm i-layers benefited from the spike annealing cycle.

A realistic application of the spike annealing concept would be to apply it once a day in a PVT system using stagnation for a short time period (1 hour). This is necessary to minimize the detrimental impact on the thermal component of the system (e.g. any thermal energy used to anneal the PV is not collected as useful thermal energy). This daily thermal annealing pulse sequence was simulated and the results are shown in Figure 7 for a $630 \mathrm{~nm}$ i-layer thick PV cell. Figure 7 compares the same cell degraded at $50{ }^{\circ} \mathrm{C}$ with and without spike annealed at $100{ }^{\circ} \mathrm{C}$ in a 12 hour cycle period for a duration of just over 1 week described in Section 2.3.

\section{\{Insert Figure 7 Here\}}

From Figure 7, the comparison between a normal $50{ }^{\circ} \mathrm{C}$ degradation to a 12 hour degradation and spike annealing cycle reveals that, over the course of just over 1 week, the spike anneal cycle test produces 8.5\% more energy if both were run for 192 hours. When comparing the two tests from the point where the normal $50{ }^{\circ} \mathrm{C}$ degradation test stabilized (140 hours) to the end of the test (192 hours), it was found that the spike annealing cycle test produced 10.6\% more energy. Since there is very little change in the spike annealing cycle test from 140 hours onwards, this would imply that over the course of the lifetime of the PVT system, applying the spike annealing once a day would produce $10.6 \%$ more energy than if the system was not annealed at all. If the a-Si:H cell was $10 \%$ efficient this would mean the cell's overall effective efficiency would increase to just over $11 \%$. These results are extremely promising as the improved performance of a-S:H PV in PVT systems using a spike annealing sequence would substantially improve the levelized cost of electricity from the devices [35].

\section{Future work}

In this study, relatively low-efficiency single junction a-Si:H devices were investigated, however, the use of a micromorph or multi-junction a-Si:H-based cells may increase the impact 
Published as: M.J.M. Pathak, J.M. Pearce and, S.J. Harrison, "Effects on Amorphous Silicon Photovoltaic Performance from High-temperature Annealing Pulses in Photovoltaic Thermal Hybrid Devices" Solar Energy Materials and Solar Cells, 100, 199-203 (2012).

http://dx.doi.org/10.1016/j.solmat.2012.01.015

of thermal annealing cycles even further because of their overall improved performance [36]. In addition, it is suggested that an i-layer thickness series study be completed utilizing spike annealing cycles at higher temperatures for a shorter period of time might also produce the same effects, but have less of a negative effect on the thermal component. Future work is needed to assess the feasibility of stagnating the PVT system to determine if the gain in exergy from the solar PV cells exceeds the losses in thermal energy output due to the stagnation period. It would also be interesting to determine the best time during a day to implement the stagnation, which would produce the required annealing temperature while minimizing the stagnation thermal losses. For example, in the middle of the day where the irradiance is highest, a high stagnation temperature can be achieved but the thermal losses would be greater than if this was completed at the end of the day.

Finally, in recent years the use of Feed-In-Tariffs (FIT) programs has been introduced to various countries to promote green technologies. In Ontario, Canada, the FIT program offers a substantial financial benefit for each kWh of solar electricity provided to the grid [37, 38]. Future work is needed to investigate both the optimal dispatch strategy of thermal annealing in PVT devices to maximize income under different FIT structures, but also can be used to encourage energy policy formation that maximizes exergy for a given technology. For example, it may therefore be more beneficial from an economic perspective to spike anneal even in the middle of the day since the electricity gained greatly exceeds the cost of purchasing it even though from an exergy or greenhouse gas mitigation standpoint later thermal cycling may be optimal. Another concept that can be explored is utilizing dispatch strategies that only allow spike annealing at times when the thermal demand is zero or when the occupants will not be using the hot water for a while, such as when the occupants of a home are on vacation. This would then have no negative impact on the performance of the thermal component while improving the electrical efficiency.

\section{Conclusions}

This paper explored the potential of thermal annealing cycles (spike annealing) of a-Si:H based PV cells by simulating high temperature sequences that would occur during imposed stagnation conditions in hybrid PVT solar collectors. Through simulating the stagnation of an a$\mathrm{Si}: \mathrm{H}$ PVT system for 1 hour where the cell was maintained at $100{ }^{\circ} \mathrm{C}$, it was found that there was $10.6 \%$ gain in solar electricity production compared to running a cell only at $50{ }^{\circ} \mathrm{C}$ once both had reached the normal $50^{\circ} \mathrm{C}$ stabilized state. Assuming the rates of degradation were maintained throughout their lifetime, the relative gain would be maintained for the cells with spike annealing. With the prospects of producing substantially more energy due to spike annealing, PVT systems have the technical potential to become a much larger fraction of the burgeoning solar market.

\section{Acknowledgements}

This work was supported by the Natural Sciences and Engineering Research Council of Canada, Canada Foundation for Innovation, Ministry of Research and Innovation, the Canadian 
Published as: M.J.M. Pathak, J.M. Pearce and, S.J. Harrison, "Effects on Amorphous Silicon Photovoltaic Performance from High-temperature Annealing Pulses in Photovoltaic Thermal Hybrid Devices" Solar Energy Materials and Solar Cells, 100, 199-203 (2012).

http://dx.doi.org/10.1016/j.solmat.2012.01.015

Solar Building Network, and PV Measurements Inc. The authors would like to acknowledge K. Girotra for providing samples.

\section{References}

[1] M.J.M. Pathak, J.M. Pearce, S.J. Harrison, Optimizing for Solar Energy Applications with Limited Solar Roof Access: Exergy Analysis of Solar Thermal, Photovoltaic, and Hybrid Photovoltaic Thermal Systems, (to be published).

[2] N.Loir, N. Zhang, Energy, exergy, and second law performance criteria, Energy 32 (2007) 445-455.

[3] M. Bakker, H.A. Zondag, M.J. Elswijk, K.J. Strootman, M.J.M. Jong, Performance and costs of a roof-sized PV/thermal array combined with a ground coupled heat pump, Sol Energy 78 (2003) 331-339.

[4] W. van Helden, R. van Zolingen, H.A. Zondag, PV thermal systems: PV panels supplying renewable electricity and heat, Prog Photovoltaics 12 (2004) 415-426.

[5] Y. Tripanagnostopoulos, M. Souliotis, R. Battisti, A. Corrado, Energy, cost and LCA results of PV and hybrid PV/T solar systems, Prog Photovoltaics 13 (2005) 235-250.

[6] H.A. Zondag, Flat-plate PV-Thermal collectors and systems: A review, Renew Sust Energ Rev 12 (2008) 891-959.

[7] T.T. Chow, A review on photovoltaic/thermal hybrid solar technology. Appl. Energ. 87 (2010) 365-379.

[8] R. Platz, D. Fischer, M.A. Zufferey, J.A.A. Selvan, A. Haller, A. Shah, Hybrid collectors using thin-film technology, 26th IEEE Photovoltaic Specialists Conf. Proc. (1997) 12931296.

[9] G. Fraisse, C. Menezo, K. Johannes, Energy performance of water hybrid PV/T collectors applied to combisystems of Direct Solar Floor type, Sol. Energ. 81 (2007) 1426-1438.

[10] H.A. Zondag, D.W. de Vries, W.G.J. van Helden, R.J.C. van Zolingen, A.A. van Steenhoven, The yield of different combined PV-thermal collector designs, Sol. Energy, 74 (2003) 253-269.

[11] P. Wormser, S. Strong, Evaluation of the Potential for Use of New Thin Film Photovoltaic Materials as Selective Surfaces for Solar Thermal Absorbers in Flat-plate Combined Photovoltaic/Thermal Collectors, ASHRAE Final Report (2006) 1109-RP.

[12] E. Schweizer, Enecolo AG, LESO-PB, New generation of hybrid solar PV/T collectors, Swiss Federal Office of Energy Final Report (2000) 56360 / 16868. 
Published as: M.J.M. Pathak, J.M. Pearce and, S.J. Harrison, "Effects on Amorphous Silicon Photovoltaic Performance from High-temperature Annealing Pulses in Photovoltaic Thermal Hybrid Devices" Solar Energy Materials and Solar Cells, 100, 199-203 (2012).

http://dx.doi.org/10.1016/j.solmat.2012.01.015

[13] D.L. Staebler and C.R. Wronski, Reversible conductivity changes in discharge- produced amorphous Si. Appl. Phys. Lett. 31 (1977) 292-294.

[14] H. Fritzsche, Development in understanding and controlling the Staebler-Wronski Effect in a-Si:H, N. Rev. Mater. Res. 31 (2001) 47-79.

[15] C. R. Wronski, J. M. Pearce, J. Deng, V. Vlahos, and R. W. Collins, Intrinsic and light induced gap states in a-Si:H materials and solar cells - effects of microstructure, Thin Solid Films 451-452 (2004) 470-475.

[16] J. Deng, M. L. Albert, J. M. Pearce, R. W. Collins, and C. R. Wronski, The nature of native and light induced defect states in i-layers of high quality a-Si:H solar cells derived from dark forward bias current-voltage characteristics, Mater. Res. Soc. Symp. Proc. 862 (2005) A11.4.

[17] Klaver and R. van Swaaij, Modeling of light-induced degradation of amorphous silicon solar cells, Sol Energ. Mat. Sol. C. 92 (2008) 50-60.

[18] C.R. Wronski, J.M. Pearce, R.J. Koval, X. Niu, A.S. Ferlauto, J. Koh, R.W. Collins, Light induced defect creation kinetics in thin film protocrystalline silicon materials and their solar cells, Mat. Res. Soc. Symp. Proc. 715 (2002) A13.4.1-A13.4.12.

[19] M.J.M Pathak, J.M.Pearce, S.J. Harrison, K. Girotra, The effect of hybrid photovoltaic thermal device operating conditions on intrinsic layer thickness optimization of hydrogenated amorphous silicon solar cells, Sol. Energy 2011 Submitted for publication...

[20] J. M. Pearce, J. Deng, M. L. Albert, C. R. Wronski, R.W. Collins, Room Temperature Annealing of Fast States from 1 sun Illumination in Protocrystalline Si:H Materials and Solar Cells, 31st IEEE Photovoltaic Specialists Conf. Proc. (2005) 1536-1539.

[21] S. Fujikake, H. Ota, M. Ohsawa, T. Hama, Y. Ichikawa, H. Sakai, Light-induced recovery of a-Si solar cells, Sol. Energy Mat. Sol. C. 34 (1994) 449-454

[22] M.L. Albert, J. Deng, X.Niu, J. M. Pearce, R. W. Collins, and C. R. Wronski, The creation and relaxation kinetics of light induced defects in a-Si:H located at different energies in the gap”, Mater. Res. Soc. Symp. Proc. 862 (2005) A13.2.

[23] J. M. Pearce, J. Deng, M. L. Albert, C. R. Wronski, and R.W. Collins, Room temperature annealing of fast states from 1 sun illumination in protocrystalline $\mathrm{Si}: \mathrm{H}$ materials and solar cells, 31st IEEE Photovoltaic Specialists Conf. Proc. (2005) 1536-1539.

[24] I. Pola, D. Chianese, L. Fanni and R. Radel, Analysis of annealing and degradation effects on a-Si modules Source: Proc:23 (2008) 2301 -2304.

[25] C. R. Wronski, J. M. Pearce, J. Deng, V. Vlahos, and R. W. Collins, Intrinsic and Light Induced Gap States in a-Si:H Materials and Solar Cells - Effects of Microstructure, Thin Solid Films, 451-452 pp. 470-475, 2004; 
Published as: M.J.M. Pathak, J.M. Pearce and, S.J. Harrison, "Effects on Amorphous Silicon Photovoltaic Performance from High-temperature Annealing Pulses in Photovoltaic Thermal Hybrid Devices" Solar Energy Materials and Solar Cells, 100, 199-203 (2012).

http://dx.doi.org/10.1016/j.solmat.2012.01.015

[26] J. M. Pearce, J. Deng, R. W. Collins, and C. R. Wronski, Light Induced Defect States in Hydrogenated Amorphous Silicon Centered Around 1.05 and $1.2 \mathrm{eV}$ from the Conduction Band Edge, Applied Physics Letters, 83 (2003) 3725-3727.

[27] J. Pearce, X. Niu, R. Koval, G. Ganguly, D. Carlson, R.W. Collins, C.R. Wronski, Contributions of DO and non-DO gap states to the kinetics of light induced degradation of amorphous silicon under 1 sun illumination, Mat. Res. Soc. Symp. Proc., 664 (2001) A12.3.

[28] R. Ruther, G. T-Mani, J. del Cueto, J. Adelstein, M.M. Dacoregio, B. von Roedern, Performance test of amorphous silicon modules in different climates - year three: higher minimum operating temperatures lead to higher performance levels, 31st IEEE Photovoltaic Specialists Conf. Proc. (2005) 1635-1638.

[29] S. Kalogirou, The potential of solar industrial process heat applications, Appl. Energ. 76 (2003) 337-361.

[30] P. Mahtani, N.P. Kherani, S. Zukotynski, The use of amorphous silicon in fabricating a photovoltaic-thermal system, Proceedings of the 2nd Canadian Solar Buildings Conference (2007).

[31] S.A. Kalogiru and Y. Tripanagnostopoulos Industrial application of PV/T solar energy systems. Appl. Therm. Eng. 27 (2007) 1259-1270 .

[32] D. L. King, J. A. Kratochvil, and W. E. Boyson, Temperature coefficients for PV modules and arrays: measurement methods, difficulties, and results, 26th IEEE Photovoltaic Specialists Conf. Proc. (1997) 1183-1186.

[33] L. Yang, L.Chen, Thickness dependence of light induced degradation in a-Si:H solar cells, J. Non-Cryst. Solids, 137-138(1991) 1189-1192.

[34] H. Fritzsche, Development in understanding and controlling the Staebler-Wronski Effect in a-Si:H, Annu. Rev. Mater. Res. 31 (2001) 47-79.

[35] K. Branker, M.J.M. Pathak, J. M. Pearce, A Review of Solar Photovoltaic Levelized Cost of Electricity, Renewable \& Sustainable Energy Reviews (in press).

http://dx.doi.org/10.1016/j.rser.2011.07.104

[36] M. Shima, M. Isomura, K.Wakisaka, K. Murata, M. Tanaka, The influence of operation temperature on the output properties of amorphous silicon-related solar cells, Sol. Energ. Mat. and Sol. C. 85(2005) 167-175.

[37] Ontario Fit Program. http://fit.energyauthority.on.ca/quick-facts-table-0

[38] Ontario Energy Board. http://www.ontarioenergyboard.ca/OEB/Consumers/Electricity/Electricity+Prices 
Published as: M.J.M. Pathak, J.M. Pearce and, S.J. Harrison, "Effects on Amorphous Silicon Photovoltaic Performance from High-temperature Annealing Pulses in Photovoltaic Thermal Hybrid Devices" Solar Energy Materials and Solar Cells, 100, 199-203 (2012).

http://dx.doi.org/10.1016/j.solmat.2012.01.015

\section{Figures}

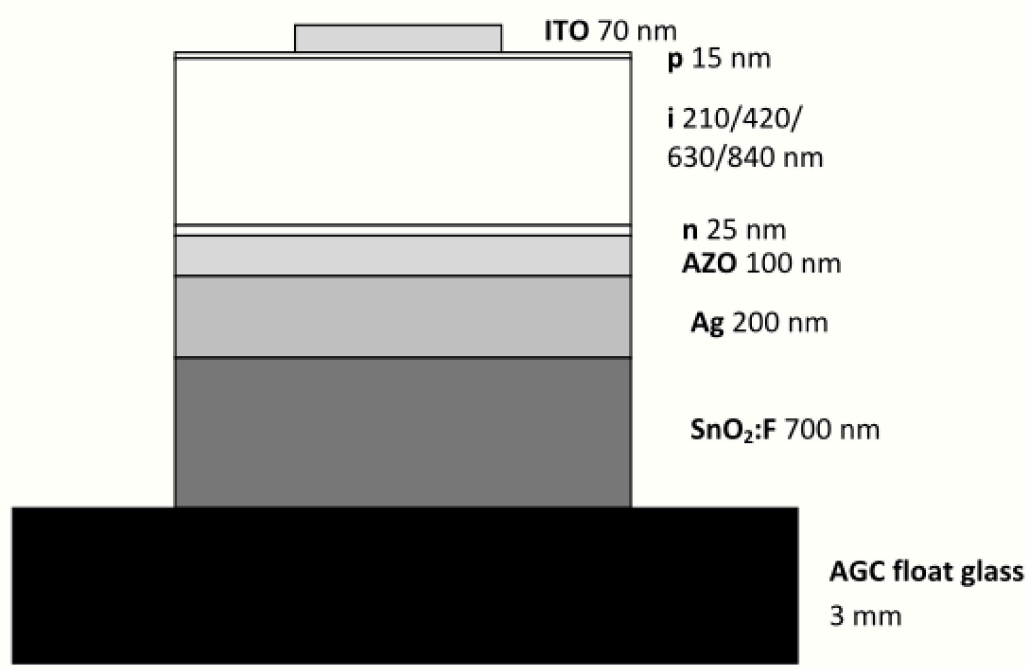

Figure 1: The composition and structure of the a-Si:H solar photovoltaic cells used in this study.

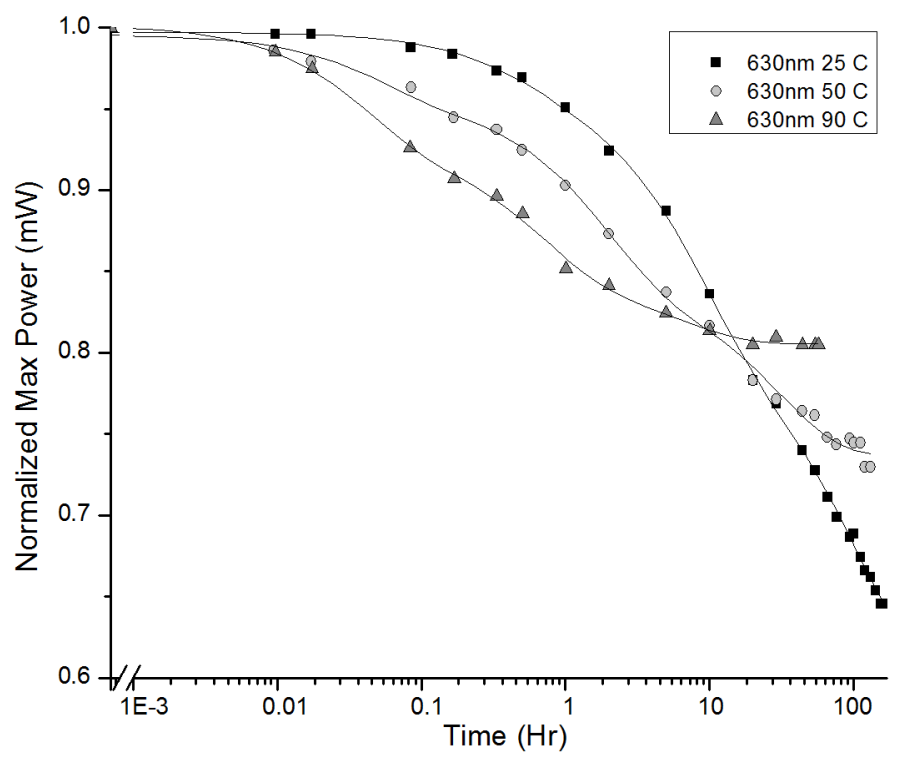

Figure 2: A normalized temperature series of 25, 50 and $90{ }^{\circ} \mathrm{C}$ degradation under 1 sun for a PV cell with an i-layer thickness of $630 \mathrm{~nm}$. 
Published as: M.J.M. Pathak, J.M. Pearce and, S.J. Harrison, "Effects on Amorphous Silicon Photovoltaic Performance from High-temperature Annealing Pulses in Photovoltaic Thermal Hybrid Devices" Solar Energy Materials and Solar Cells, 100, 199-203 (2012).

http://dx.doi.org/10.1016/j.solmat.2012.01.015

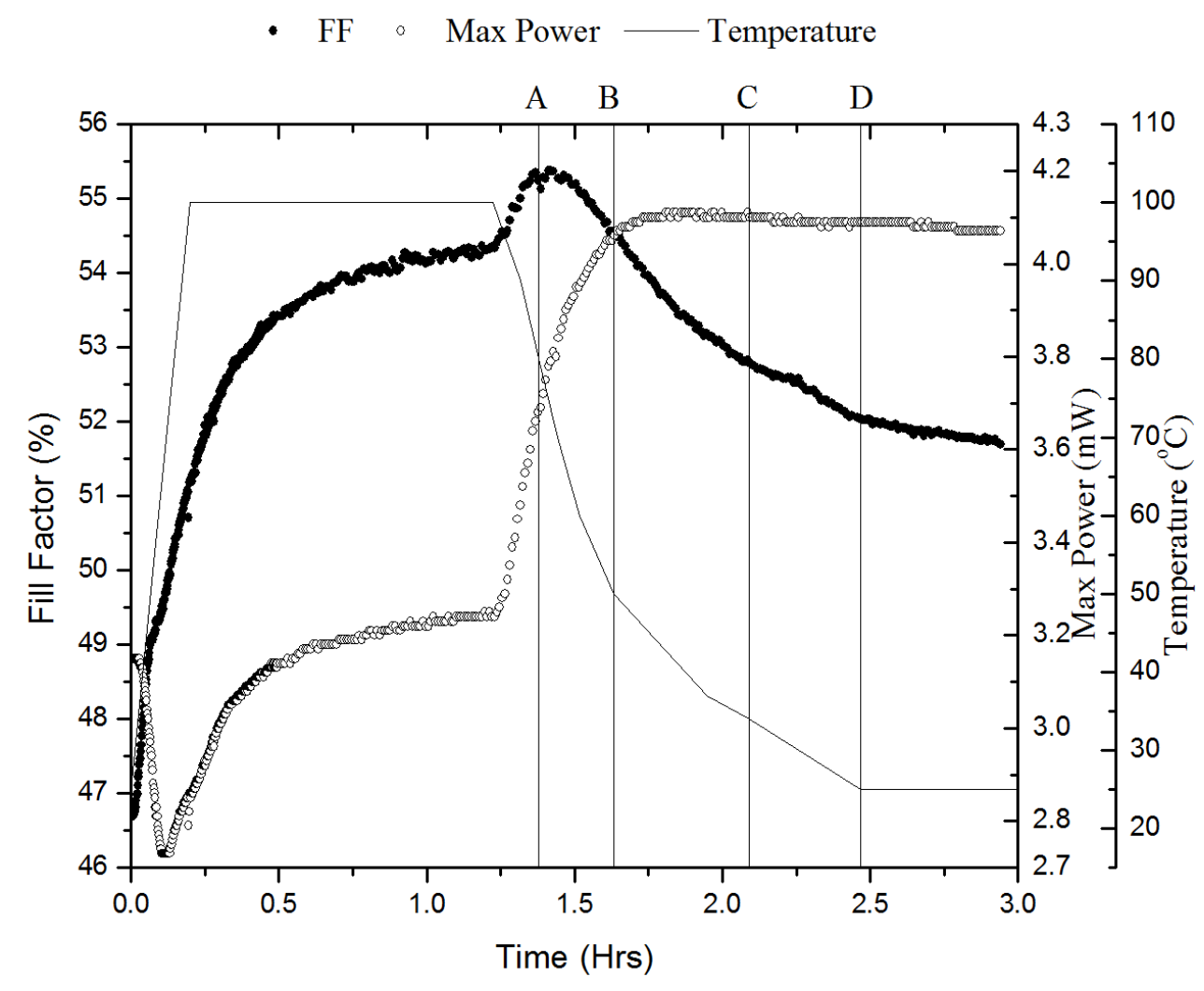

Figure 3: High-temperature annealing pulses (spike annealing) results for $25^{\circ} \mathrm{C}$ degradation showing the fill factor, maximum power and temperature $\left(\mathrm{A}: 80^{\circ} \mathrm{C}, \mathrm{B}: 50^{\circ} \mathrm{C}\right.$, C: fan turned on, D: $25{ }^{\circ} \mathrm{C}$ ) as a function of time. 
Published as: M.J.M. Pathak, J.M. Pearce and, S.J. Harrison, "Effects on Amorphous Silicon Photovoltaic Performance from High-temperature Annealing Pulses in Photovoltaic Thermal Hybrid Devices" Solar Energy Materials and Solar Cells, 100, 199-203 (2012).

http://dx.doi.org/10.1016/j.solmat.2012.01.015

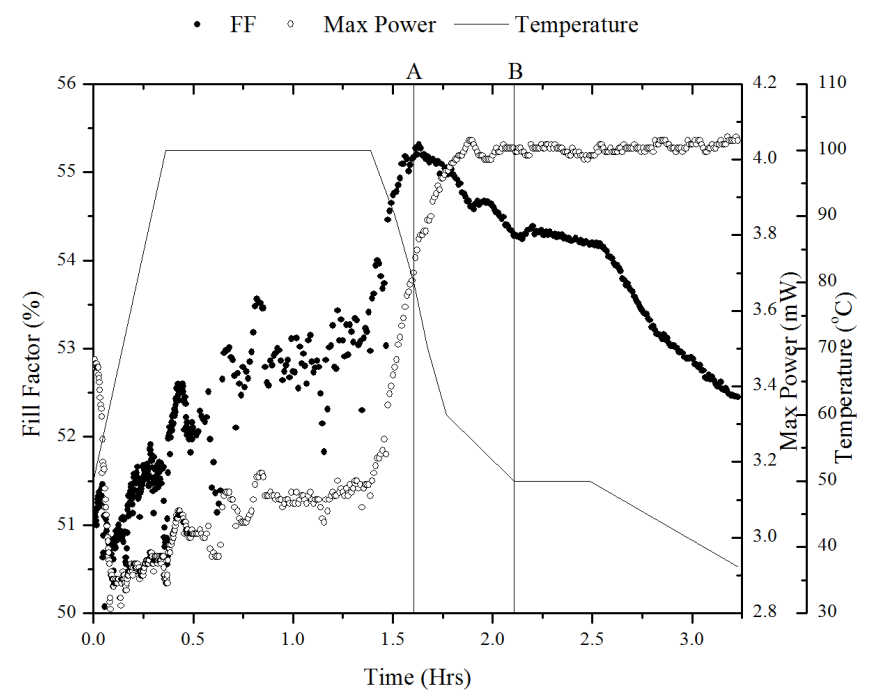

Figure 4: High-temperature annealing pulses (spike annealing) results for $50{ }^{\circ} \mathrm{C}$ degradation showing the fill factor, maximum power and temperature $\left(\mathrm{A}: 80^{\circ} \mathrm{C}, \mathrm{B}: 50^{\circ} \mathrm{C}\right)$ as a function of time.

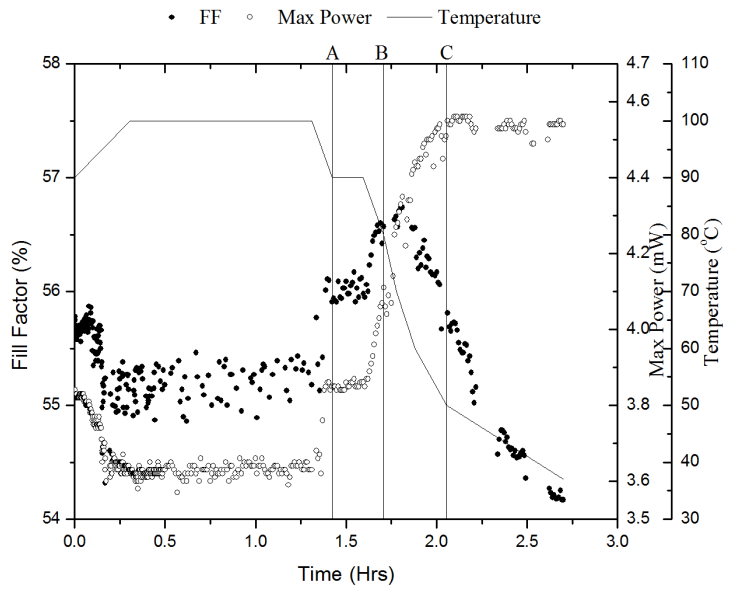

Figure 5: High-temperature annealing pulses (spike annealing) results for $90{ }^{\circ} \mathrm{C}$ degradation showing the fill factor, maximum power and temperature $\left(\mathrm{A}: 90^{\circ} \mathrm{C}, \mathrm{B}: 80^{\circ} \mathrm{C}, \mathrm{C}: 50{ }^{\circ} \mathrm{C}\right)$ as a function of time. 
Published as: M.J.M. Pathak, J.M. Pearce and, S.J. Harrison, "Effects on Amorphous Silicon Photovoltaic Performance from High-temperature Annealing Pulses in Photovoltaic Thermal Hybrid Devices" Solar Energy Materials and Solar Cells, 100, 199-203 (2012).

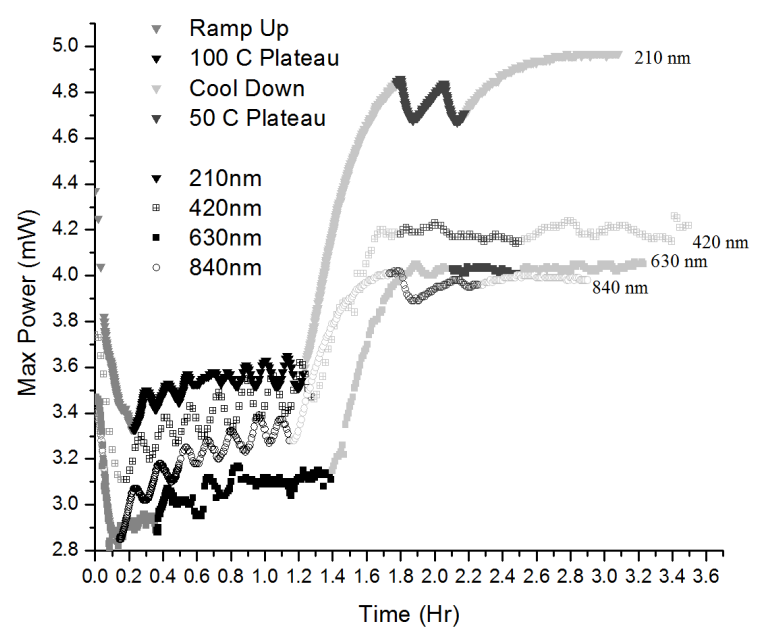

Figure 6: High-temperature annealing pulses (spike annealing) thickness series showing the maximum power as a function of time using a-Si:H cells with i-layer thicknesses of 210, 420, 630 and $840 \mathrm{~nm}$ degraded at $50{ }^{\circ} \mathrm{C}$ under 1 sun. The color of the symbols indicates the stage of the temperature cycle.

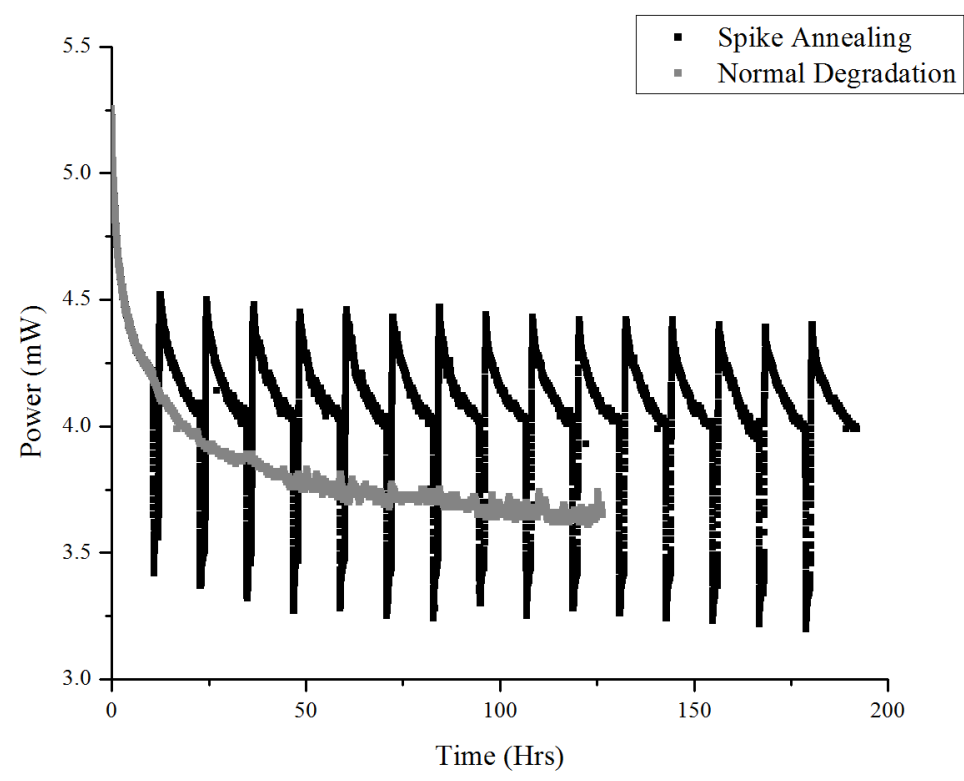

Figure 7: Comparison of the same $630 \mathrm{~nm}$ i-layer thick a-Si:H PV cell degraded at $50{ }^{\circ} \mathrm{C}$ under 1 sun (Normal Degradation) to results obtained for degradation at $50{ }^{\circ} \mathrm{C}$ under 1 sun coupled with spike annealing at $100^{\circ} \mathrm{C}$ on a 12 hour cycle for 192 hours (Spike Annealing). 